\title{
Analisis Nilai Tambah Edamame Melalui Penanganan Pasca Panen menggunakan Air Berozon
}

\section{The Added-Value Analysis of Edamame In Ozonated Water Post-Harvest Handling}

\author{
Silvia Oktavia Nur Yudiastuti ${ }^{\# 1}$, Rizza Wijaya*2 \\ \# Jurusan Teknologi Pertanian, Politeknik Negeri Jember, Indonesia \\ ${ }^{1}$ Email : silvia.oktavia@polije.ac.id \\ *Jurusan Teknologi Pertanian, Politeknik Negeri Jember, Indonesia
}

\begin{abstract}
The value-added analysis is one of the most important investors instruments in determining the type and level of technology that will be used in the production process. The Food products added-value analysis of food products calculate the product added value due to the addition of technology types and or levels in the food processing process. The value-added analysis method used to analyze fresh edamame in this research was Hayami and Kawagoe. Edamame post-harvest processing is an important critical point in the production of fresh edamame. Abiotic contamination, presence of pesticide residues, vitamin $\mathrm{C}$ oxidation, food fiber ingredients, sensory value, and color stability in post-harvest handling are some of the quality criteria that are important to be met. This research aim was to compare the fresh edamame value-added products handling using ozonated water technology with chlorine disinfection that has previously been used. Based on the research results, the added value of edamame minimal processing with ozone was $145 \mathrm{IDR} / \mathrm{kg}$ higher than chlorine processing. The addition of $45 \mathrm{IDR} / \mathrm{kg}$ as ozone technology effort investment in the edamame minimal processing has increased the edamame value-added ratio by $0.19 \%$.
\end{abstract}

Keywords: Chlorine, Edamame, Hayami and Kawagoe, Ozonized water, Product value-added

\section{Pendahuluan}

Analisis nilai tambah adalah analisis terhadap pertambahan nilai yang diperoleh oleh suatu komoditas produk, yang muncul karena bahan mentah produk tersebut mendapatkan suatu proses pengolahan sehingga menjadi lebih bernilai [3]. Harga proses produksi tersebut menjadi nilai tambah yang perlu dianalisis untuk mengetahui nilai produk tersebut jika akan dilakukan peningkatan skala produksi [9].

Perhitungan nilai tambah dalam penelitian ini menggunakan metode Hayami dan Kawagoe [11], karena dengan nilai tambah yang diperoleh lebih mewakili besarnya nilai tambah yang diterima dari kegiatan pengolahan. Terdapat dua cara dalam menghitung nilai tambah, yaitu dengan menghitung nilai tambah selama proses pengolahan dan menghitung nilai tambah selama proses pemasaran. Dalam penelitian ini, akan dilakukan analisis nilai tambah pengolahan pasca panen edamame menggunakan air berozon.
Nilai tambah adalah penambahan nilai suatu komoditas karena adanya input fungsional yang diberlakukan pada komoditas bersangkutan [12]. Input fungsional tersebut berupa proses pengubahan bentuk (from utility), pemindahan tempat (place utility), maupun penyimpanan (time utility). Nilai tambah menggambarkan imbalan bagi tenaga kerja, modal dan manajemen. Tujuan dari analisis nilai tambah adalah untuk mengukur balas jasa yang diterima pelaku sistem (pengolah) dan kesempatan kerja yang diciptakan oleh system tersebut [5].

Pengukuran nilai tambah dengan menggunakan metode Hayami dan Kawagoe dilakukan dengan menghitung nilai tambah produk yang diakibatkan oleh pengolahan dan tidak memasukan penggunaan tenaga kerja dan faktor produksi yang lain. Jika faktor tenaga kerja dimasukkan maka nilai yang didapatkan adalah keuntungan perusaahan dan bukan nilai tambah dari suatu proses. 


\section{Materi Dan Metode}

Penelitian dilakukan pada bulan Agustus Desember 2020 yang bertempat di Laboratorium logam, Laboratoriun analisis pangan, Laboratorium Teknologi Pengolahan Pangan dan Laboratorium Komputer Jurusan Teknologi Pertanian Politeknik Negeri Jember. Bahan yang digunakan dalam penelitian adalah edamame lokal jember yang dibeli di pasar Tanjung Kabupaten Jember, akuades, air keran, Nutrien agar (Oxoid), serta klorin dan bahan kimia pegujian (Merck). Alat yang digunakan dalam penelitian adalah mesin pencuci dengan teknologi ozon yang dirakit di Laboratorium Logam Jurusan Teknologi Pertanian Politeknik Negeri Jember [7], cawan petri, laminar, autoclave, inkubator, coloni counter, buret dan erlenmeyer untuk titrasi.

Metode penelitian yang digunakan adalah metode eksperimental, data diolah menggunakan perangkat lunak microsoft exel pada data kuantitatif dalam bentuk tabulasi, microsoft word dan microsoft visio dengan metode Hayami dan Kawagoe untuk selanjutnya dianalisis secara deskriptif. Analisis niai tambah dilakukan pada edamame segar yang diolah minimal menggunakan pencucian dengna air berozon dan air berklorin konsentrasi $175 \mathrm{ppm}$. Pencucian ozon dilakukan menggunakan mesin pencuci ozon kontinyu dengan waktu ozonasi 15 menit dan waktu kontak ozon 24 menit. Kondisi pengolahan minimal edamame melalui pencucian dilakukan dengan kondisi seperti disajikkan pada Tabel 1.

\begin{tabular}{lll}
\multicolumn{1}{c}{$\begin{array}{c}\text { TABEL 1. KONDISI PER Unit PENCUCIAN EDAMAME } \\
\text { Kriteria }\end{array}$} & $\begin{array}{c}\text { Pencucian Ozon } \\
\text { Pencucian } \\
\text { Klorin }\end{array}$ \\
\hline Kapasitas Bak & $150 \mathrm{~L}$ & $150 \mathrm{~L}$ \\
\hline Sistem operasi & Kontinyu & Batch \\
\hline Kondisi Operasi & $\begin{array}{l}\text { Ozonasi 15 Menit } \\
\text { Kontak 24 Menit }\end{array}$ & Kontak 40 menit \\
\hline Batch/hari & 8 & 6 \\
\hline Konsumsi Air & $100 \mathrm{~L} /$ hari & $700 \mathrm{~L} / \mathrm{hari}$ \\
\hline Edamame dicuci & $40 \mathrm{Kg} / \mathrm{batch}$ & $40 \mathrm{Kg} / \mathrm{batch}$ \\
\hline Konsumsi Klorin & - & $122,5 \mathrm{gr} / \mathrm{hari}$ \\
\hline Kemasan & $320 \mathrm{pcs} / \mathrm{batch}$ & $240 \mathrm{pcs} / \mathrm{batch}$ \\
\hline Tenaga Kerja & 3 & 5
\end{tabular}

Data yang digunakan dalam penelitian adalah data primer baik data harga bahan baku maupun hasil analisis dari penelitian penanganan pasca panen dengan teknologi air berozon dengan pembanding pencucian dengan klorin.

\section{A. Proses Pengolahan Minimal}

Proses pengolahan dimulai dengan meisahkan edamame dari kotoran batu - batu besar. Tangki pencuci dialiri dengan air sesuai dengan kapasitas, untuk dengan teknologi ozon, mesin dinyalakan untuk mensirkulasikan ozon dalam air selama 15 menit. Edamame ditimbang dan kemudian dimasukan dalam tangki pencuci ozon, mesin ozon tetap menyala selama 15 menit dan dimatikan. Edamame didiamkan dalam tangki tertutup tersebut selama 24 menit. Udara dalam air rendaman dialirkan untuk mengetahui residu konsentrasi ozon, sedangkan residu pestisida dan total mikroba diuji dari sampel edamame hasil perendaman. Mesin ozon dinyalakan kembali untuk proses selanjutnya. Edamame diambil dengan cara pengangkat saringan dalam tangki, air pencucian tetap dapat digunakan selama 1 hari proses produksi secara kontinyu.

Pencucian dengan klorin dimulai dengan menyiapkan klorin $175 \mathrm{ppm}$ dalam air pencuci yang sudah dialirkan dalam bak, kemudian disirkulasikan. Edamame ditimbang dan dimasukan dalam bak pencuci, didiamkan selama 40 menit. Edamame diambil menggunakan saringan. Air pencucian diganti setiap dua kali pencucian.

\section{B. Analisis Nilai Tambah}

Komponen analisis nilai tambah metode Hayami dan Kawagoe yang diamati dalam penelitian ini adalah informasi :

- Nilai tambah $(\mathrm{Rp} / \mathrm{Kg})$ yaitu pertambahan nilai pada komoditas yang telah mengalami proses pengolahan, pengemasan, pengangkutan, maupun penyimpanan sehingga menjadi suatu produk yang akan dipasarkan atau dijual ke konsumen $\begin{aligned} \text { Nilai tambah }(\mathrm{Rp} / \mathrm{Kg})= & \text { Nilai Output }(\mathrm{Rp} / \mathrm{Kg})-\text { Harga Bahan } \\ & \text { Baku }(\mathrm{Rp} / \mathrm{Kg})-\text { Sumbangan input } \\ & \text { lain }(\mathrm{Rp} / \mathrm{Kg})\end{aligned}$

- Rasio nilai tambah terhadap nilai produk yang dihasilkan (\%), menunjukkan persentase nilai tambah dari nilai produk.

Rasio Nilai tambah $(\mathrm{Rp} / \mathrm{Kg})=($ Nilai Tambah $(\mathrm{Rp} / \mathrm{Kg}) / \mathrm{Nilai}$ Output $(\mathrm{Rp} / \mathrm{Kg}))$ x $100 \%$

- Bagian tenaga kerja (\%), menunjukkan persentase imbalan tenaga kerja dari nilai tambah.

Bagian Tenaga Kerja $(\%)=((($ Jumlah tenaga kerja (orang)/Input bahan baku (kg)) $\mathrm{x}$ Upah tenaga kerja (Rp/Orang) ) / Nilai Tambah $(\mathrm{Rp} / \mathrm{Kg})) \times 100 \%$

$$
\text { ......(3) }
$$

- Tingkat keuntungan (\%) menunjukkan persentase keuntungan terhadap nilai tambah

$$
\begin{aligned}
& \text { Keuntungan }(\mathrm{Rp} / \mathrm{Kg})=(\text { (Nilai Tambah }(\mathrm{Rp} / \mathrm{Kg})-((\mathrm{Jumlah} \\
& \text { tenaga kerja }(\text { orang }) / \text { Input bahan } \\
&\text { baku }(\mathrm{kg})) \times \text { Upah tenaga kerja } \\
&(\mathrm{Rp} / \mathrm{Orang}))) / \text { Nilai Tambah } \\
&(\mathrm{Rp} / \mathrm{Kg})) \times 100 \% \\
& \ldots \ldots . .(4)
\end{aligned}
$$

- Marjin, menunjukkan besarnya kontribusi pemilik faktor produksi selain bahan baku yang digunakan dalam proses produksi. 
Silvia Oktavia Nur Yudiastuti, Rizza Wijaya. Analisis Nilai Tambah Edamame Melalui Penanganan Pasca Panen menggunakan Air Berozon

$\operatorname{Margin}(\mathrm{Rp} / \mathrm{Kg})=(($ Output $(\mathrm{Kg}) /$ Input $(\mathrm{Kg})) \times$ Harga Output $(\mathrm{Rp} / \mathrm{Kg})$ ) - Harga Bahan Baku (Rp/Kg)

\section{Pengujian Konsentrasi Ozon}

Konsentrasi ozon dianalisis menggunakan metode titrasi iodimetri. $200 \mathrm{ml} \mathrm{KI} 2 \%$ yang telah dialirkan ozon dengan laju alir $1 \mathrm{~L} /$ menit selama 1 menit dititrasi dengan $\mathrm{Na}_{2} \mathrm{~S}_{2} \mathrm{O}_{3} 0,2 \mathrm{~N}$ hingga kuning pucat, ditambahkan $10 \mathrm{~mL} \mathrm{H}_{2} \mathrm{SO}_{4} 0,1 \mathrm{~N}$ dan $0,5 \mathrm{~mL}$ amilum $2 \%$. Larutan dititrasi kembali dengan $\mathrm{Na}_{2} \mathrm{~S}_{2} \mathrm{O}_{3} 0,2 \mathrm{~N}$ hingga berwarna biru gelap [10].

[Ozon] $(\mathrm{g} / \mathrm{L})=\left(24 \times \mathrm{N} \mathrm{Na}_{2} \mathrm{~S}_{2} \mathrm{O}_{3}(\mathrm{~L}) \times \mathrm{N} \mathrm{Na}_{2} \mathrm{~S}_{2} \mathrm{O}_{3}\right) / \mathrm{V}_{\text {sampel }}(\mathrm{L})$

\section{Residu Pestisida}

Dilakukan berdasarkan prinsip titrasi agrentometri. $5 \mathrm{~mL}$ sampel ditambahkan $0,2 \mathrm{~mL}$ $\mathrm{K}_{2} \mathrm{CrO}_{4} 5 \%$, kemudian dititrasi dengan $\mathrm{Ag}_{2} \mathrm{NO}_{3}$ hingga warna putih menjadi merah keruh [6].

[Residu Pestisida] $\left.(\mathrm{mg} / \mathrm{L})=\underset{\operatorname{sampel}(\mathrm{L})}{\mathrm{Nag}} \mathrm{Ag}_{2} \mathrm{NO}_{3} \times \mathrm{Mg}_{2} \mathrm{NO}_{3} \times 5,84\right) / \mathrm{V}$
samel

\section{E. Pengujian Total Mikroorganisme}

Melakukan pengencern sampel dengan cara melarutkan $1 \mathrm{~mL}$ sampel dalam $9 \mathrm{~mL} \mathrm{NaCl} 0,85 \%$ hingga pengenceran $10^{-6}$. Jumlah sel dihitung pada 3 pengenceran terakhir dengan metode BAM [2].

\section{Hasil Dan Pembahasan}

Pada penelitian dilakukan perhitungan dengan tiga kriteria harga yaitu pada saat harga rendah (1), pada saat harga normal (2) dan harga tertinggi di pasaran (3). Penggunaan tiga variasi harga dimaksudkan untuk memberikan gambaran keuntungan yang diperoleh pada saat harga tertinggi di pasaran. Berdasarkan hasil penelitian, rincian harga bahan yang digunakan dalam penelitian disajikkan pada Tabel 2.

Tabel 2. Biaya BAHAN BAKU Dalam PRoses Pengolahan MINIMAL EDAMAME

\begin{tabular}{lccc}
\hline & \multicolumn{3}{c}{ Harga Satuan } \\
\cline { 2 - 4 } & $\mathbf{1}$ & $\mathbf{2}$ & $\mathbf{3}$ \\
\hline Edamame (Rp/Kg) & 8.000 & 12.000 & $\begin{array}{c}16.00 \\
0\end{array}$ \\
\hline Air Keran (Rp/L) & 5 & 6 & 7,5 \\
\hline Klorin (Rp/gr) & 30 & 35 & 50 \\
\hline Kemasan Vacum Bag (Rp/pcs) & 1.200 & 1.800 & 2.200
\end{tabular}

Bahan baku adalah bahan habis pakai yang digunakan dalam produksi edamame pengolahan minimal. Biaya lain yang dikeluarkan dalam proses pengolahan, disebut dengan sumbangan input lain. Biaya tersebut dalam peneltian ini adalah alat yang dibangun untuk pengolahan minimal edamame yang meliputi alat pencuci teknologi ozon kontinyu pada pengolahan minimal dengan ozon dan bak pencuci permanen yang dibangun untuk pencucian dengan klorinasi. Alat proses lain yang digunakan adalah unit pengemas vakum. Rincian biaya input lain yang digunakan dalam penelitian disajikkan pada Tabel 3 .

Tabel 3. Biaya Sumbangan InPut Lain dalam Proses Pengolahan Minimal Edamame (DAlam 1 TahUN)

\begin{tabular}{lccc} 
& \multicolumn{3}{c}{ Harga } \\
\cline { 2 - 2 } & $\mathbf{1}$ & $\mathbf{2}$ & $\mathbf{3}$ \\
\hline $\begin{array}{l}\text { Sealer Vakum } \\
\text { (Rp/Unit) }\end{array}$ & 1.500 .000 & 2.500 .000 & 3.000 .000 \\
\hline $\begin{array}{l}\text { Rancang bangun alat } \\
\text { ozon (Rp/unit) }\end{array}$ & 3.500 .000 & 4.000 .000 & 4.500 .000 \\
\hline $\begin{array}{l}\text { Rancang bangun bak } \\
\text { pencuci (Rp/unit) }\end{array}$ & 4.000 .000 & 4.500 .000 & 5.000 .000 \\
\hline
\end{tabular}

Tabel 3 menunjukkan bahwa biaya rancang bangun pencucian ozon lebih rendah dari pencucian dengan klorinasi. Pencucian dengan klorinasi membutuhkan tempat lebih luas dan proses lebih panjang dari pencucian dengan ozon.

Harga bahan baku dari Tabel 2 dan sumbangan input lain dari tabel 3 disubsitusikan data kondisi pencucian edamame dari Tabel 1 pada bagian metode penelitian, sehingga didapatkan variabel harga pada Tabel 4 yang merupakan komponen perhitungan analisis nilai tambah metode Hayami dan Kawagoe.

TABel 4. Harga Bahan BaKU dan Sumbangan InPUT LaIN DALAM PRODUKSI EDAMAME DENGAN PENGOLAHAN MINIMAL

1 tahun $=12$ bulan $\times 4$ minggu $\times 5$ hari $=240$ hari

1 hari $=8$ siklus proses produksi

\begin{tabular}{lll} 
& $\begin{array}{c}\text { Pengolahan } \\
\text { Ozon }\end{array}$ & $\begin{array}{c}\text { Pengolahan } \\
\text { Klorin }\end{array}$ \\
\hline Bahan Baku $(\mathrm{Kg})$ & 320 & 240 \\
\hline Produk $(\mathrm{Kg})$ & 320 & 240 \\
\hline Tenaga Kerja (Orang) & 3 & 5 \\
\hline Hari Kerja & 5 & 5 \\
\hline $\begin{array}{l}\text { Upah Tenaga Kerja } \\
\text { (Orang/Hari) }\end{array}$ & $\mathrm{Rp} \mathrm{50.000}$ & $\mathrm{Rp} \mathrm{50.000}$
\end{tabular}

\begin{tabular}{|c|c|c|}
\hline \multicolumn{3}{|l|}{ Bahan Baku } \\
\hline Kondisi 1 (Rp) & 2.944 .500 & 2.215 .175 \\
\hline Kondisi 2 (Rp) & 4.416 .600 & 3.320 .488 \\
\hline Kondisi 3 (Rp) & 5.824 .750 & 4.379 .375 \\
\hline \multicolumn{3}{|c|}{ Sumbangan Input Lain } \\
\hline Kondisi $1(\mathrm{Rp})$ & 5.000 .000 & 5.500 .000 \\
\hline Kondisi 2 (Rp) & 6.500 .000 & 7.000 .000 \\
\hline Kondisi 3 (Rp) & 7.500 .000 & 8.000 .000 \\
\hline Harga Produk (Rp) & $70.000 / \mathrm{Kg}$ & $70.000 / \mathrm{Kg}$ \\
\hline
\end{tabular}

Berdasarkan Tabel 4 dapat dijelaskan bahwa dalam 1 tahun terdiri dari 240 hari kerja. Perbedaan antara pengolahan minimal edamame dengan ozon dan klorin adalah jumlah batch produksi (Tabel 1). Pengolahan minimal dengan ozon, dapat memproses edamame dengan batch lebih banyak dari pengolahan dengan klorin, sebab pengolahan dengan ozon dilakukan menggunakan mesin yang berproses secara kontinyu, sedangkan pada pengolahan dengan klorin menggunakan bak pencuci yang tidak dilakukan secara kontinyu. Air pencuci yang digunakan pada 
metode pencucian bak klorin tidak dapat terus digunakan, perlu diganti setiap akan dilakukan pencucian. Jumlah tenaga kerja pada proses pengolahan dengan klorin lebih banyak 2 orang dari pengolahan dengan ozon, sebab membutuhkan lebih banyak langkah kerja dan sistem belum diotomasisasi. Upah dan jumlah tenaga kerja serta jam kerja pekerja pada pengolahan minimal dengan ozon dan klorin adalah sama.

Harga bahan baku dalam perhitungan analisis nilai tambah adalah harga bahan baku pada Tabel 4 yang dibagi dengan jumlah kebutuhan $\mathrm{Kg}$ bahan baku yang digunakan dalam satu hari proses produksi. Harga produk yang digunakan dalam analisis nilai tambah adalah harga eceran tertinggi per $\mathrm{Kg}$ produk yang dijual di pasaran dengan metode pencucian klorin. Harga bahan baku pada pengolahan dengan ozon lebih besar dari harga pengolahan dengan klorin, hal tersebut karena jumlah batch pengolahan minimal edamame dengan ozon $4 / 3 \mathrm{kali}$ lebih banyak dibandingkan dengan pengolahan minimal klorin sehingga jumlah edamame dan bahan kemas yang dibutuhkan lebih banyak.

Nilai bahan baku, produk, harga bahan baku, harga produk, dan tenaga kerja dari Tabel 4 digunakan untuk menghitung nilai tambah edamame hasil pengolahan minimal dengan ozon dan klorin melalui metode Hayami dan Kawagoe. Hasil analisis nilai tambah edamame pengolahan minimal, ditambah dengan beberapa indikator kriteria mutunya disajikkan pada Tabel 5.

TABel 5. Perbandingan Analisis Nilai TAMbaH DaN INDIKATOR LAIN PRODUKSI EDAMAME DENGAN PENGOLAHAN MiNIMAL (HARGA 3)

\begin{tabular}{lcc}
\multicolumn{1}{c}{ Indikator } & $\begin{array}{c}\text { Pengolahan } \\
\text { Ozon }\end{array}$ & $\begin{array}{c}\text { Pengolahan } \\
\text { Klorin }\end{array}$ \\
\hline Nilai Tambah $(\mathrm{Rp} / \mathrm{Kg})$ & 50.496 & 50.364 \\
\hline Rasio Nilai Tambah & $72,14 \%$ & $71,95 \%$ \\
\hline Bagian Tenaga Kerja & $0,93 \%$ & $2,07 \%$ \\
\hline Tingkat Keuntungan & $99,07 \%$ & $97,93 \%$ \\
\hline Margin (Rp/Kg) & 51.798 & 51.753 \\
\hline Residu Pestisida (mg/L) & $0,12 \pm 0,11$ & $1,73 \pm 0,01$ \\
\hline Total Mikroba (CFU/gr) & $3,79 \pm 0,25$ & $5,84 \pm 0,32$
\end{tabular}

Hasil analisis nilai tambah yang disajikan pada Tabel 5 adalah berdasarkan harga bahan baku dan harga sumbangan input lain dengan harga paling maksimal di pasar (harga 3). Berdasarkan Tabel 5 diketahui bahwa nilai tambah pengolahan minimal ozon memberikan nilai tambah lebih besar dari pengolahan klorin sebesar Rp 132/Kg. Hal tersebut menunjukkan bahwa penerapan teknologi ozon pada pengolahan minimal edamame dapat memberikan kelebihan nilai edamame yang sebesar Rp 132/Kg. Rasio nilai tambah edamame segar pengolahan minimal ozon lebih besar $0,19 \%$ dibandingkan dengan hasil pengolahan dengan klorin. Hal tersebut menunjukkan bahwa penerapan teknologi pengolahan pasca panen edamame dengan ozon memberikan nilai tambah sebesar $0,19 \%$ dari nilai produk lebih besar dari pengolahan dengan klorin. Bagian tenaga kerja dengan pengolahan ozon lebih kecil $1,14 \%$ dibandingkan dengan pengolahan menggunakan klorin. Pertambahan teknologi dalam proses produksi dapat menurunkan nilai bagian tenaga kerja, sebab dapat menurunkan kontribusi tenaga kerja dalam proses produksi. Semakin besar input teknologi yang digunakan dalam suatu proses produksi, imbalan atau bagian tenaga kerja akan semakin rendah. Keuntungan pengolahan minimal edamame dengan ozon lebih besar $1,14 \%$ dari pengolahan dengan klorin. Nilai selisih antara pengolahan minimal ozon dengan klorin pada komponen bagian tenaga kerja dan keuntungan seimbang. Keuntungan menunjukkan besarnya presentase nilai tambah akibat penambahan teknologi tanpa memperhitungkan komponen bagian kontribusi tenaga kerja, sehingga pengurangan nilai pada bagian tenaga kerja akan sebanding dengan nilai positif yang diperoleh pada keuntungan produk dari pertambahan nilai akibat penambahan kualitas proses produksi.

Marjin keuntungan pengolahan minimal edamame dengan ozon lebih besar $\mathrm{Rp} 45 / \mathrm{Kg}$ dari pengolahan dengan klorin. Hal tersebut menunjukkan bahwa kontribusi pemilik modal terhadap keuntungan yang diperoleh akibat penambahan teknologi ozon meningkat sebesar $\mathrm{Rp} 45 / \mathrm{Kg}$ dibandingkan pengolahan dengan klorin. Berdasarkan nilai marjin dapat dijelaskan bahwa proses produksi mempengaruhi harga bahan baku yang pada akhirnya mempengaruhi nilai tambah, keuntungan dan bagian tenaga kerja dalam nilai tambah produk. Harga bahan baku tidak mempengaruhi tenaga kerja dan harga output, tetapi turut mempengaruhi nilai tambah produk. Semakin tinggi harga bahan baku, nilai tambah produk akan semakin rendah.

Nilai tambah pengolahan minimal edamame dengan ozon dan klorin dalam penelitian ini adalah \pm $50 \%$ lebih tinggi dari perhitungan nilai tambah Hayami dan Kawagoe yang melakukan perhitungan nilai tambah pada pengolahan pasca panen pertanian yang mencapi maksimal pada nilai tambah $40 \%$. 
Silvia Oktavia Nur Yudiastuti, Rizza Wijaya. Analisis Nilai Tambah Edamame Melalui Penanganan Pasca Panen menggunakan Air Berozon

Nilai tambah dipengaruhi juga oleh kapasitas produksi, pada pencucian dengan dengan ozon yang memiliki kapasitas lebih besar, menghasilkan nilai tambah yang lebih besar pula dibandingkan dengan pencucian dengan klorin. Peningkatan rendemen hasil produksi dan kapasitas produksi dapat meningkatkan nilai tambah dan rasio nilai tambah produk [6].

Konsentrasi mikroorganisme patogen total pada perlakuan dengan ozon lebih rendah dibandingkan dengan pencucian klorin. Residu pestisida yang terdapat pada edamame hasil pencucian ozon juga lebih rendah dibandingkan hasil pencucian dengan klorin. Hal tersebut menunjukkan bahwa ozon bersifat sebagai oksidator yang lebih baik dibandingkan klorin dalam menurunkan mikroorganisme dan residou pestisida. Penelitian yang sama menunjukkan bahwa ozon dapat menurunkan mikroorganisme lebih banyak dibandingkan klorin dan dapat mempertahankan warna hijau lebih baik pada pencucian edamame segar [1].

Berdasarkan perhitungan, nilai residu ozon yang terkandung dalam edamame setelah diolah minimal ozon dengan waktu ozonasi 15 menit dan waktu kontak ozon 24 menit adalah 0,012 ppm. Bau ozon sudah tidak terdeteksi setelah dikontakan selama 24 menit setelah 15 menit diozonasi, bau ozon tidak tercium pada air cucian maupun edamame hasil pencucian. Nilai maksimal ozon menurut OSHA (Ocupational Safety and Health Administration) adalah $0,01-0,05$ ppm untuk menghasilkan bau ozon [4].

Penggunaan ozon dalam bidang pangan telah disetujui oleh FDA (Food and Drug Administration) untuk digunakan sebagai antimikroba pada pengolahan bahan makanan dan penyimpanan makanan. Penggunaan ozon lainnya saat ini banyak diaplikasikan diberbagai bidang, seperti untuk pemurnian air minum, sterilisasi bahan mentah, pengawetan bahan makanan, sterilisasi peralatan kedokteran, pengolahan air untuk keperluan air pendingin, pengolahan limbah cair hasil industri dan hasil pemurnian minyak, mengontrol bau dan warna, serta pembuatan ultrapure water pada indutri elektronik [8].

\section{Kesimpulan Dan SARAN}

Berdasarkan hasil pengamatan dan analisis data disimpulkan sebagai berikut :

- Nilai tambah edamame segar pengolahan minimal dengan teknologi ozon lebih tinggi dari hasil pengolahan minimal dengan klorin

- Nilai tambah edamame pengolahan minimal dipengaruhi oleh proses pengolahannya.

- Residu ozon dalam edamame setelah waktu ozonasi 15 menit dan waktu kontak 24 menit adalah $0,012 \mathrm{ppm}$
- Jumlah total mikroorganisme dan residu pestisida pada edamame segar hasil pengolahan minimal dengan ozon lebih rendeah dari hasil pengolahan dengan klorin.

Saran yang dapat diberikan berdasarkan hasil penelitian adalah pengujian penggunaan alat untuk pengolahan minimal hasil komoditas pertanian, perkebunan, kehutanan dan peternakan lainnya.

\section{UCAPAN TERIMA KASIH}

Ucapan terima kasih kami sampaikan pada Politeknik Negeri Jember yang telah mendanai penelitian ini melalui skema sumber dana PNBP Tahun 2020

\section{Daftar Pustaka}

[1] A. Bakri, W. Suryaningsih, B. Hariono, and S. Hartatik, "Perbaikan Kualitas dan Dekontaminasi Mikroba Kedelai Edamame Dengan Teknik Ozonated Water," J. Ilm. Inov., vol. 18, no. 1, 2018, doi: 10.25047/jii.v18i1.919.

[2] A. Zapata and S. Ramirez-Arcos, "A Comparative Study of McFarland Turbidity Standards and the Densimat Photometer to Determine Bacterial Cell Density," Curr. Microbiol., vol. 70, no. 6, pp. 907909, 2015, doi: 10.1007/s00284-015-0801-2.

[3] D. Uswatun Hasanah, Mayshuri, "Analisis Nilai Tambah Agroindustri Sale Pisang di Kabupaten Kebumen The Value Added Analysis of Sale Pisang Agroindustry in Kebumen Regency," vol. 18, no. 3, pp. 141-149, 2015, doi: 10.1111/j.13652699.2006.01584.x.

[4] J. C. Ku, "Ozone In Workplace Atmospheres (Impregnated Glass Fiber Filter)," OSHA Salt Lake Tech. Cent., pp. 1-35, 2008, [Online]. Available: https://www.osha.gov/dts/sltc/methods/inorganic/id2 14/id214.html.

[5] N. Elfriyani, Z. Alamsyah, and Elwamendri, "ANALISIS NILAI TAMBAH DAN PROSPEK PENGEMBANGAN AGROINDUSTRI DODOL TOMAT," Sosio Ekon. Bisnis ISSN 1412-8241, vol. 15, no. 1, pp. 57-64, 2012, doi: 10.22437/jiseb.v15i1.2743.

[6] R. Yanuasari, Khusna Ismiya Hartadi and S. Raharto, "ANALYSIS OF INCOME AND VALUE ADDED AND AGRO-INDUSTRY DEVELOPMENT STRATEGY NUTS ROASTED AT CV. TDS MITRA GARUDA IN JEMBER," Agritrop J. IlmuIlmu Pertan., no. 2, pp. 126-136, 2018.

[7] S. Yudiastuti and R. Wijaya, "Mesin Pencucian Teknologi Ozon untuk Sayur dan Buah Sebagai Penurun Kadar Residu Pestisida," S00202006229, 2020.

[8] Syarifudin, Angky, and Novia, "Produksi Ozon dengan Bahan Baku Oksigen Menggunakanan Alat 
Jurnal Ilmiah INOVASI, Vol. 21 No. 1 Januari-April 2021, ISSN 1411-5549

Ozon Generator,” Tek. Kim., vol. 2, no. 19, 2013.

[9] U. Tadulako, "Analysis Of Cattle Abon Added Value In Home Industry Mutiara $\mathrm{Hj}$. Mbok Sri In Palu City," Pembang. Ekon. Indones., 2018.

[10] W. J. Masschelein, L. Blaich, B. Langlais, E. Thieben, and J. Bell, "Ozone: Science \& Engineering: The Journal of the International Ozone Association Ozone Science \& Engineering Special Issue on Quality Assurance in Ozone Practice," no. October 2014, pp. 37-41, doi: $10.1080 / 01919519809480354$

[11] Y. Hayami and T. Kawagoe, "Farm mechanization, scale economies and polarization. The Japanese experience," J. Dev. Econ., vol. 31, no. 2, pp. 221239, 1989, doi: 10.1016/0304-3878(89)90013-8.

[12] Y. Rok and L. Ph, "Converting citrus wastes into value-added products: Economic and environmently friendly approaches," Nutrition, vol. 34, pp. 29-46, 2017, doi: 10.1016/j.nut.2016.09.006. 